\title{
“SILENCE OF ACADEMY": EXPRESSING HARASSMENT THROUGH COLLECTIVE DESIGN PROCESS (1)
}

\author{
Ece CANLI* , Çiğdem KAYA**
}

Received: 06.11.2014; Final Text: 05.01.2016

Keywords: Gender and design; participatory action research; practice-based research; sexual harassment; socially and politically engaged design.

1. This research was carried out as an MFA degree project at Konstfack University College of Arts, Crafts and Design in Stockholm, Sweden between 2011-2012 under the supervisions of Rolf Hughes, Petra Bauer and Çiğdem Kaya.

2. The first person stands for the first author of the article as the conductor of the research. Throughout the article, we maintain the use of first person pronoun considering the referees' request and the characteristics of self-reflexive feminist wording.

\footnotetext{
* Faculty of Fine Arts, University of Porto, Porto, PORTUGAL.

** Department of Industrial Product Design, Istanbul Technical University, Istanbul, TURKEY.
}

\section{INTRODUCTION}

Today design practice is more integrated with social issues than in the era of its emergence in the mid-twentieth-century insomuch as it has created its discourses under the names of critical design, design activism, participatory design, co-design, community-based design, social design, design as politics, exploratory design and so forth (Fuad-Luke, 2009). While the fields of interest within the socially responsible subcategories in design vary from environmental issues to the critique of consumption culture, utilising design practice for the benefit of unprivileged groups in society still needs more practical implementations accompanied by an active and direct participation of the groups in question. Starting off from this idea, the practice-led design research entitled Silence of Academy centred on women as an unprivileged group and their everyday experience of sexual harassment as a form of oppression, humiliation and exclusion. Carried out during 2011-2012 in Istanbul, Turkey, in collaboration with women activist undergraduate students, this research investigated ways of using design activity as a tool to express women's suffering derived from gender discrimination.

To build a bridge between the design process and the issue of sexual harassment as an important subject matter in feminist agenda, I (2) will first expand on the problem of sexual harassment and the consequential resistance by women. Next, I will briefly discuss the collective expression and the resistance of women against patriarchy within the wider context of design. After I have introduced the methodological approach of the research including Participatory Action Research (PAR), storytelling, nondocumentation and self-representation-all of which helped to deploy design activity in an urgent socio-political context-I will instantiate the political potential of design through the practice Silence of Academy. Meanwhile, considering my role not only as a design researcher but also as an activist in women's resistance against sexual harassment, I will 
3. Referring sexual harassment as a problem of women does not mean that I ignore harassment towards other gender identities, sexualities and sexual orientations. However, within the woman-centred feminist scope of this article, I rather follow Catharina MacKinnon who states that "mostly sexually harassed people are women" (MacKinnon, $1979,193)$ since gender as a socially constructed phenomenon (Butler, 1990) is still firmly connected to sex and sexual identity.

4. An undergraduate organisation that is a part of the feminist collective "Dikkat Taciz Var!" (Watch Out! Sexual Harassment!) and the study group of this research.

5. Although their overt counteraction against sexual harassment derived from the cumulative stories of sexual harassment directed at students by professors, during discussions on policies, the participants widened academia to other actors in a university such as secretariat, administrative department, student affairs and other hierarchal organisations. Participants also problematised harassments directed from student to student, by analysing hegemonic masculinity in both institutional and personal level. draw attention to the shift in the position of the design researcher from leading maker to facilitator via full participation in action research. I will conclude by reflecting on the possible ways of empowering women in their resistance through design activity, supporting them to reclaim their own agency and to represent themselves with their very own tools.

\section{THE ISSUE OF SEXUAL HARASSMENT AND WOMEN'S RESISTANCE}

From the mid-nineteenth-century until the late 1970s, the first and second wave of feminist movements achieved a phenomenal success in women's rights, from gaining legitimate identity before the state, including suffrage to reawakening women's consciousness about education, abortion, child care and reproductive rights (Dicker and Piepmeier, 2003). But even though since the 1980s, third wave feminism has been contributing to the broader struggle for gender identity, driven by the discussions around intersectionality, sexual diversity and neoliberal politics of women's labour, long-standing problems such as domestic violence, rape and sexual harassment have yet to be sufficiently addressed by the second and third wave generations (Dicker and Piepmeier, 2003; Hayes, 2007). In the case of Turkey, the voice of the feminist movement only started to address these issues in the late 1980s by organising several crucial demonstrations. One of them was Mor İğne (Purple Needle) (1989), a protest against sexual harassment that resulted in significant changes in the Turkish Civil Code and Penal Code for the benefit of women (Moralıoğlu, 2012).

Nevertheless, as a result of the law not being properly upheld, and of patriarchy being so deeply rooted both in the social and in the political realm, sexual harassment remains as one of the most crucial obstacles to women's liberation.(3) It is usually defined as any kind of unwanted sexual imposition ranging from verbal sexual jokes, taunts, physical contacts such as squeezing or hitting accidentally to forced sexual relations (MacKinnon, 1979) or plain "girl watching" as "the act men's sexually evaluating women" (Quinn, 2002, 387). As such, sexual harassment is not only about sexual desire, but more about the desire of power and domination (MacKinnon, 1979; Bingham, 1994; Quinn, 2002; Uggen and Blackstone, 2004; Robinson, 2012; McLaughlin et al., 2012). As an enactment of hegemonic heteronormative masculinity (Connell, 1987) that subjugates all other forms of gender performativities (Butler, 1990), sexual harassment reproduces power relations, maintaining the subordination of men to women physically, discursively and psychologically (Bingham, 1994). It violates women's bodies, destroying their existence in any active social relationship (Jackson, 2002; Arendt, 1944), sweeping them out of public space to domesticated private spaces (Ehrnberger et al., 2012) and depriving them of their rights to participate politically in everyday life (Rancière, 2007). Therefore, counteraction against this deeply entrenched problem by women asks for a strategic approach emanating from within women's daily life experiences.

The urge to develop new alternative strategies to dysfunctional policies in the context of sexual harassment was the very agenda of Mimar Sinan University of Fine Arts (MSGSU) Women's Association (4) during the academic year 2011-2012. They focused particularly on academia (5) where power relations operate in such a complex hierarchal and bureaucratic system that women often get silenced, oppressed and subjugated even more, as their experiences are rendered invisible. Focusing on sexual 
harassment within schooling, Robinson (2012) draws attention to this invisibility by indicating how hierarchies of power in institutional practices constitute perpetrators as authoritative figures, complicating any form of action. In schools, students keep more silent about sexual harassment due to various reasons such as the power of professors giving grades and recommendation letters to students or the fear of stigmatisation among the schoolfellows; therefore, harassment remains a "hidden issue" (Paludi, 2011, ix-x). This became apparent during the meetings of the Association, when a significant number of stories that remained untold due to shame, fear of failure or threats by perpetrators came to light. It is also the reason why it was not possible to give accurate numerical statistics of sexual harassment cases since they are rarely reported or stated out loud. Even if a woman makes an occasional public complaint, she is not taken seriously. Rancière helps us to understand this public ignorance as a strategy of the sovereign: the key way to deprive people, who are unwanted in public space, of their political power is to pretend not to understand them or not to hear what they say (Rancière, 2007); as to make them mute and invisible.

Taking these complexities and inadequacies of policies regarding sexual harassment into account, MSGSU Women's Association started to look for new strategies to empower women to be outspoken and also to intervene/ interrupt patriarchal public space with their own voices by adopting unconventional ways. Being a member of the Dikkat Taciz Var! Collective before conducting this research, I also became involved in this process and investigated possible ways of using design as a political practice.

\section{WOMEN'S RESISTANCE WITHIN AND THROUGH DESIGN}

In order to undermine the system of patriarchy with the tools of a discipline like design, one must first understand the ways in which the discipline itself has been complicit in the hegemonic structures at hand. As an inseparable part of the system, design practice reflects a wider reality of male domination. This fact can be seen in many design dichotomies such as "function over decoration [...], public over private, [...] and design over taste equated male over female" (Clark, 2009, 293). The design discipline has been objectifying women by either using them as a visual means to attract consumption or by targeting them as consumers in relation to the modernist ideology of buying life and as representation of alleged liberated sexual desire (Gorman, 2001). Even in narratives recounted about female designers, women have been related to the realm of the soft and the domestic, whereas man dominates the arena of hard production and machines where "form (female) follows function (male)" (Attfield, 2009, 49). Design, as it can be seen, has been just another realm where hegemonic masculinity is perpetuated and reinforced.

Despite the dramatic move in feminism and its echoes in visual arts consolidating women's resistance since the early 1960s, gender discussions and awareness in design remained largely overlooked until the 1980s. Early criticism of man-dominated design discipline focused on the man-generated design practice which excluded female designers from technology-oriented design areas by associating them with soft and domestic fields such as fashion, jewellery and crafts (Kaygan, 2009). Other feminist critiques and projects followed soon after in the forms of writing women into design history and design theory (Buckley, 1989; Kirkham, 1996), reflecting upon the demographic information of women and men in the design industry related to production and technology (Attfield, 1989) 
and focusing on the division between the private and public realm that secludes women indoors whilst liberating men in social life (Hayden, 1982). Finally, the other critiques were on writing about how aesthetic taste is taken for granted and working on the commercial side of design that uses women as objects of desire in advertisements of designer goods (Sparke, 1995).

Thanks to the contributions of the earlier design scholars and practitioners, the relationship between women and design was altered, and the emphasis shifted from the question of visibility of women designers to an entirely new feminist approach within design (Attfield 1989; Ferrara, 2012). This change paved the way for analysing the ways in which design enforces conventional dichotomised gender relations and generates gender stereotypes, revealing also the gender discrimination present in the very discipline itself (Ferrara, 2012). Although to reposition women designers more visibly does help to alter the situation of women within the discipline positively, there is an also risk that exclusive implementations might render women even more excluded and marginalised (Gorman, 2001) or misrepresented by repeating gender stereotypes (Canl1, 2014). More importantly, feminist design scholarship and practice still lack direct contribution to women's resistance against inequalities in socio-political realm whereas design has a direct impact on the social construction of our visual, material and spatial environments. As Buckley (1989) pointed out, the current situation still requires more elaborate research, new redefinitions of what constitutes design, and a widening of the borders of design concerning its relationship to other disciplines-such as politics and gender studies.

This shortfall and need have been addressed by successor designers and activists whose focus was to approach design from a politically engaged perspective and to contend for women's visibility in and outside the design discipline. For instance, Barcelona-based urban design collective Col-Lectiu Punt 6 (6) uses the tools they have as designers and activists to eliminate gender discrimination in public space by involving women in their participatory processes for improving non-gendered environments together. Another activist project entitled The Experience of a Resistance (7) which was initiated as an experimental platform of visual, oral and material testimonies of women telling their experiences of violence, aimed to create a collective resistance via sharing similar forms of resistance through design act. Besides these examples, there are activist campaigns such as the worldwide known Hollaback (8), an online platform against sexual harassment that visually maps the locations of recounted violence accompanied by the narrators' true life experiences. Even though it was not intended to function as a design project in the first place, it did use design's visual, virtual and spatial tools to raise awareness and empowerment among women in resistance. However, the number of similar design-led works of which focus is not only on the predicaments of woman designers but also of women in general, is still lacking. Therefore, the discussion on gender inequality needs to be expanded to outside design's disciplinary interests.

6. For more information, see http://www. punt6.org

7. The project was carried out in 2011-2013 in Iran and Sweden. For more information, see http://www.experienceofresistance.com/

8. For more information, see http://www. ihollaback.org/
Taking into account the need to explore the relationship between design and gender issues, the initial focus of the research entitled Silence of Academy was women's resistance facilitated through design, rather than deploying design as the ultimate goal for production. Therefore, women's direct participation in the project was substantial. It was also an alternative 
to the conventional characteristics of design that divides communal space and helps the distribution of-what Rancière calls-the common, via the processes of inclusion and exclusion (Rancière, 2007). By fostering participation, observation and self-representation, the design process was experienced as an activation of agency rather than as a pacifier of public opinion (Bonsiepe, 2006) in the context of sexual harassment against women. Just as Attfield suggests, such an approach strengthens the point "at which a criterion can be constructed which does not refer everything back to market forces or abstract aesthetics" (Attfield, 2009, 52) and allows for real intervention in a patriarchal world. In the next chapter, I will elaborate the methodological approach of the research with its driving forces.

\section{METHODOLOGY}

During my practice-led research that aimed to exercise design not only for women, but also by women, I used Participatory Action Research (PAR) (Pain et al., 2012). The most important reason is that PAR enables oppressed groups to express themselves and to act and produce transformative knowledge together (Fals borda and Rahman, 1991), whilst blurring the boundaries between the subject and the object of the research (Gaventa, 1988). Simultaneously, the methods of practice were reinforced by Critical Action Research and Feminist Emancipatory Research that encouraged dialogic engagement with women and specifically dealt with "power, politics and the subject" (Youdell, 2007) as the primary interests of the issue of sexual harassment and politically engaged design. Besides the engagement of woman activists, my position in the participation was equally important. This will be explained in the next sections, alongside the other adopted methods regarding documentation of the process, representation of participants and narrativity. Finally, self-reflexivity will be emphasised as a significant element of feminist research before the methodological analyses will be concluded with the proposal for future practices (Figure 1).

\section{Participation: A Radical Shift in the Position of the Designer}

Regarding the project's involvement with gender issues and collective action, various qualitative research methods were put into practice. First of all, the project was, in many ways, delicate due to the vulnerability of the participants. For the participants to recount their experiences openly and confidentially, I needed to reconfigure my position in the group not as an activist, but as a design researcher. This position was divided into researcher-self, who was seeking new ways of creating counter pressure through the deed of design, and activist-self who was contributing to the collective's strategies by utilising design. While my designer-as-activist side provided practical materials (i.e. creating posters, websites, placards, materials for demonstrations, videos, and stickers, as well as concept developments for particular actions) and was therefore participant, my design-researcher side kept distance from the group and from the discussed issue by being an observer in order to investigate potential methods of the discipline. This two-folded position situated me both inside and outside the process, yet they were not in opposition to each other, but rather intertwined. As an observer, my objective was to construct a conceptual and applied reality of human life based on the everyday existence (Jorgensen, 1989). This positioning let me understand the issue 
Figure 1. Diagram of the research process designed by the first author.

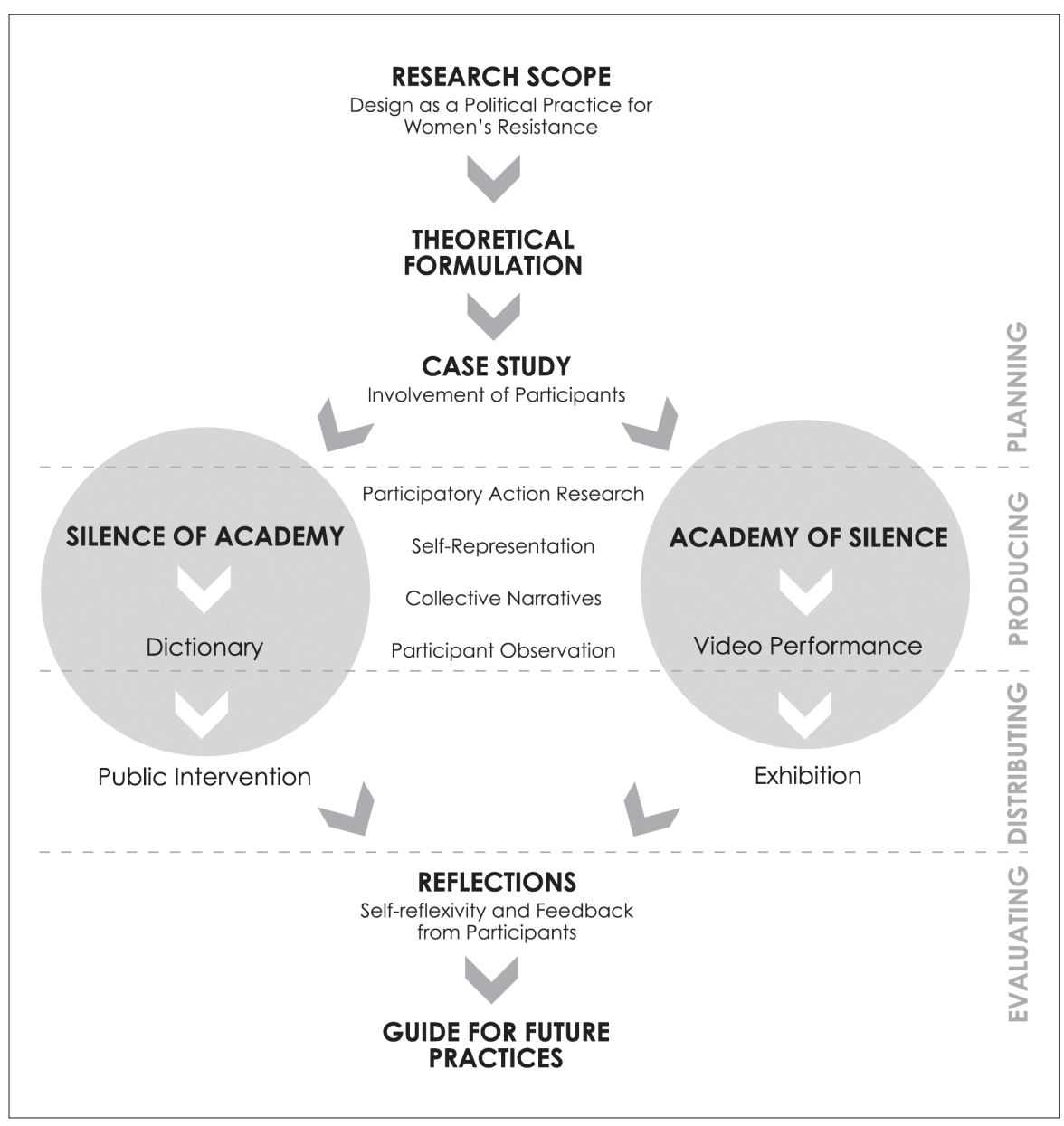

from the position of the participants by being both an insider and an outsider of the recounted narratives (Spradely, 1980).

In addition to my position, it is important to stress that my involvement with the participants and my interest in the subject matter had been built long before this research officially took place. This prior relationship enabled me to be aware of certain aspects meanwhile taking a step back as a researcher for veridical analyses. Moreover, since participant observation is particularly used as research method when the phenomenon under discussion is obscured from the outside and hidden from the public view (Jorgensen, 1989, 12-13), sexual harassment can be considered as a particularly disguised topic and due to its personal nature, it requires an insider's perspective. It also made me feel more comfortable during the activities.

Another key point is that while my position as a researcher and an activist was two-folded, it was never dimidiated, as it was eventually carried out by the same person. It enabled me to understand what collective and subjectivity could be (Rancière et al, 2001); a subjectivity that allowed participants to have their own political stances and voices within the group, meanwhile embodying these different voices into one collective identity. This mutual separation shed light on the difference between designer-asruler and designer-as-enabler (Kaya, 2010) in the case of socially engaged practices. The desire was not to rule or to dominate the process for the sake 
of a design production but to take an action on the issue in question that the collective stood against.

\section{Documentation through Self-Representation}

Being a design researcher under the roof of an institution demanded some formalities such as documenting, circumstantiating and finally exhibiting the outcomes for a certain group of audiences. Nevertheless, in my research practice, the will and the decisions of the group members had the precedence at all times. Therefore, bearing the group members' request in mind, I used no audio-visual documentation during the workshops in which private experiences were shared. Although visual data collecting methods such as photography and video shooting are commonly used to represent visually groups under study (Marshall and Rossman, 2006) especially in visual anthropology (Collier, 1967), sociology (Becker, 1974) and art \& design (Cross, 1984; Cornock, 1987), due to the sensitivity and vulnerability of the issue, my personal diary was the only record of the sessions for the personal analyses at a later time.

Moreover, unlike conventional research in humanities, arts and social sciences including design research that apply mostly visual or statistical data documentation and represent the majority of the group under study in an inductive way, in the last workshop, I adopted a process-based practice in which production and documentation were held in parallel by participants themselves. The process of producing the content of the dictionary as one of the outcomes of the workshops where participants wrote their definitions, told their stories and included their visual narratives occurred at the same time as the dictionary was shaped by the use of the participants' preferred media.

This process I call self-documentation, which refers to the technique of moment-to-moment writing by the participants during the workshop, enabled the participants to document their process of creation

simultaneously. It also goes hand in hand with self-representation, which allowed participants to communicate directly with the audience without any second actor involved. Contrary to today's modern democracy that recognises only privileged groups who are able to speak out (Bourdieu, 1999), overlooking those voices that are inaudible, oppressed or defined as inadequate or uneducated (Young, 2000; Sanders, 1997), in this project participants expressed themselves through various instruments, from photography to poetry, chosen by them as to allow them to represent themselves in their own specific ways.

\section{Collective Narratives}

In parallel to the approaches mentioned above, direct representation and unmediated communication also have great importance, especially in the case of storytelling as another milestone method in this research. Storytelling has a broad range of use from social sciences to artistic fields and can be exercised orally, bodily, textually or visually while it is particularly prominent in psychology/psychotherapy (Polkinghorne, 1998) as a therapeutic method. It is also used in trauma studies where formal expressions are insufficient for accessing unconscious psychic material (Robinett, 2007). Since it tries to "examine and analyse the subjective experience of individuals and their constructions of the social world" (Jones, 1983, 147; Marshall and Rossman, 2006) and concentrates on "critical and fateful" moments (Marshall and Rossman, 2006), sharing stories can both provide more intimate information about individual 
9. This comment came from feedback given by the women who accessed the online version of the dictionary. experiences and also paint a broader picture of the culture, environment and conditions that narrators live in. It is also a reason for storytelling to be used in feminist studies as a way of apprehending the ways in which women's lives evolve and in this manner it frees women's narratives from the constraints of male-domination (Marshall and Rossman, 2006).

Likewise, the main approach in this research was based on narratives, collectivism and "the articulation of the idiosyncratic as something common to everyone" (Jackson, 2002, 100). Employing storytelling, which enables diverse groups to meet each other's interests and to act collectively (Polletta, 2006), participants could create a collective identity within the group. It is one of the possibilities that encourages women to support each other in standing up against hegemonic power and manipulation. It allows them to represent themselves, not by male-dominated rule-maker media, but with their tools and with their free will and agency.

As individual testimonies enabled members of the group feel an instant connection with the issue and inter se (9), the concept of collective narratives was used as a supplementary tool for design activity;

"[...] Collective Narrative is a sort of collection, compilation and articulation of individual stories and experiences in groups of people who have faced similar complications either by being neglected, oppressed, excluded and victimised or being devoted to these challenges and critical situations [...] Inherently, the exploratory characteristic of collective narrations transforms itself into a constructive ground where people would be able to proceed towards movements by means of deliberations." (Canl1, 2012,32)

Shared narratives that were manifested in different visual, textual and material forms such as photographs, performances and poems could communicate in different contexts intuitively by people who shared similar experiences; they could understand and relate to each other across considerable linguistic and cultural barriers. Design, at this stage, played a subsidiary role that functioned hand in hand with shaping the process. Metaphorically, if design were a language in this process, Collective Narrative would be letters and words: they make each other mutually communicable, meaningful and help to create empowerment within and outside the group.

\section{SILENCE OF ACADEMY: DESIGN AS A POLITICAL PRACTICE}

Concerning the intentions of empowering women and in order to increase their visibility through design, the research focused on sexual harassment and was conducted in collaboration with feminist activist women in Istanbul within the context of design research and its potential implementations. The research comprised of four workshops, the first three of which functioned as a space to share experiences, discussions and the creating of visual materials for street actions. The fourth one resulted in the production of a dictionary as a communal design artefact. Furthermore, this artefact was distributed as a public intervention and therewith functioned as yet another form of collective action.

Silence of Academy started in November 2011 with a series of workshops that were initiated by me, accompanied by feminist members of MSGSU Women's Association who had been already working on the issue of sexual harassment in universities. My contact with the Association was rather an informal one, since most of the members were also active in Dikkat Taciz Var! Collective in which I was already taking part as an activist. With the 
shared subject matter in hand, the communication and the exchanging of ideas prior to the workshops took place within the email group of Dikkat Taciz Var!, and through personal meetings with some of the group members who spread the open call for the workshops to the members of MSGSU Women's Association and the undergraduate women in the universities. As most of the prospective participants were quite enthusiastic and willing to make these activities happen, there were no difficulties in organising and spreading the workshops call.

The number of participants varied from 8 to 10 during the workshops, while in the final one there were 7. Participants were middle-class undergraduate women between 18 and 23 years old, studying in different departments at different universities. They identified themselves as woman and experienced or witnessed sexual harassment at least once in their life including in academic environments. Although other cases of sexual harassment from various aggrieved parties under the roof of universities were incorporated in the discussions (i.e. women in administrative offices, teaching positions, research departments or logistics), workshops were open mainly for the undergraduate students. The main reason behind this decision was to encourage young students to openly speak of their experiences in a trustworthy environment without enforcing any formal or hierarchical power positions.

After the first workshops in which existing regulations and policies about sexual harassment in universities in Turkey were discussed (10), the group's focus shifted from the judiciary process to possible civil actions. The need for empowerment and the search for alternative ways of creating visible interventions brought about other strategies. As group members articulated their interests to expand the discussions, I proposed a final workshop dedicated to share experiences and explore possibilities for further actions. The proposal, inspired by earlier ideas that were brought forward by some of the participants, was to produce a tool for intervention in the public space in the form of a dictionary book. The dictionary is also a symbolic artefact in the sense that dictionaries are consulted and used by the academia to impose fixed normative knowledge. Hence, our own dictionary was designed to circulate in universities to disturb, interrupt and, via its mordacious content, to redefine the words, reconstruct the narratives and re-situate the image of the victim-woman.

Before the last workshop, I prepared invitations and materials to be used inside the dictionary which consisted of cards in different sizes to write the definitions of the words proposed by the participants (Figure 2). During the workshop, participants and I went one by one through all the letters of the alphabet and came up with words that reminded us of different concepts related to the issue of sexual harassment, academy and power, as well as with terms for norms and clichés that stimulate various forms of harassment (Figure 3). Most of the deconstructed words were deeply rooted in everyday language either as insults and stigmas or as desires and taboos for women in society. For instance, as the word slut signifies loose and hussy woman both in dictionaries and in everyday language to despise and moralise women's manners, participants redefined it from different point of views: while one of the participants wanted to reveal the hypocrisy of men who could use this word for attractive women whilst

10. By the time the workshops were carried out, there were only four universities in Turkey that had had policies or regulations about sexual harassment while four other universities' endeavours were in the pipeline. desiring them, another participant mentioned how sexual assaulters justify their actions by using the word as "she was a slut anyway". One of them satirically and straightforwardly unfolded the underlying meaning of slut 
as an almost open invitation for assault. Finally, the last one drew attention to the fact that any woman can be denominated by such an insult and can be stigmatised in any moment in public space (Figure 4). Likewise, the rest of the words written into the dictionary (Appendix 1) were directly or indirectly related to sexual harassment, the participants reconstructed the words' meanings, connotations and daily use sometimes in a satiric and intriguing way, sometimes with spunk and anguish.

Apart from the redefinitions of the words, as a part of the collective narratives, participants' recounted real life experiences played a significant role in the dictionary, especially regarding empowering and ensuring each other that the experiences were similar. During the process, neither stories nor words preceded one another, but one brought out the other by inducing new conversations like a snowball. Moreover, as one of the participants likewise indicated, "[...] all the words are connected to harassment and to each other, so any of them can be linked via the phrase 'see also', just like in the dictionaries"' (Field notes, 2012).

In sharing their experiences, participants brought up how justification of sexual harassment through the attributed image of women as slut, non-virgin, or promiscuous is permeated deeply into all institutions. For instance, one of the participants recalled how hospitals were more or less equal to universities in terms of their hierarchal structure and power relations where some doctors presume that they are in the position to exercise control over the patients by knowing their intimate and personal information. To the extent that a gynaecologist can implicitly condemn a young woman because of her sexual activity (Figure 6). This story sparked other similar stories allowing participants to recognise that they were not alone.

Besides the personal stories stimulated by the words inside the dictionary we were making, there were also recollections of hate speeches towards women blundered by famous figures in media who had the considerable power of manipulating public opinion. For example, the redefinitions of the word woman in our dictionary started out as a counteraction to a public figure who had spoken about women in a very demeaning way (Figure 7 ). Lastly, since the content of the dictionary was neither rhetorically nor visually didactic, we also added some symbolic references such as letters like $\breve{G}$ which connotes exclusion, exception and weakness in the Turkish language as it can never commence a word and it is called as soft (Figure 5). Furthermore, metaphors were supported by the photos, as another form of narrating, a visual one, that were taken by some of the participants during the entire series of workshops. The visual language of the photos was as strong as the verbal and textual content of the dictionary in the way that they depicted particular records of the moments and places where harassment was experienced such as the windows of a particular spot in the school or a tambourine that was played against it as the tool of audible resistance to speak up against it as an alarm (Figure 8).

When the content and different media of narrations was ready, I individually agglomerated the materials together in the form of a dictionary and brought the copies first to the participants in an informal meeting. It was the first reaction to the dictionary of a collective work by the members of the group itself. All the participants enjoyed and appreciated the workshop and they were rather motivated by the process of creating something collectively. Furthermore, some of them requested a future series of the similar workshops for a broader intervention: a 

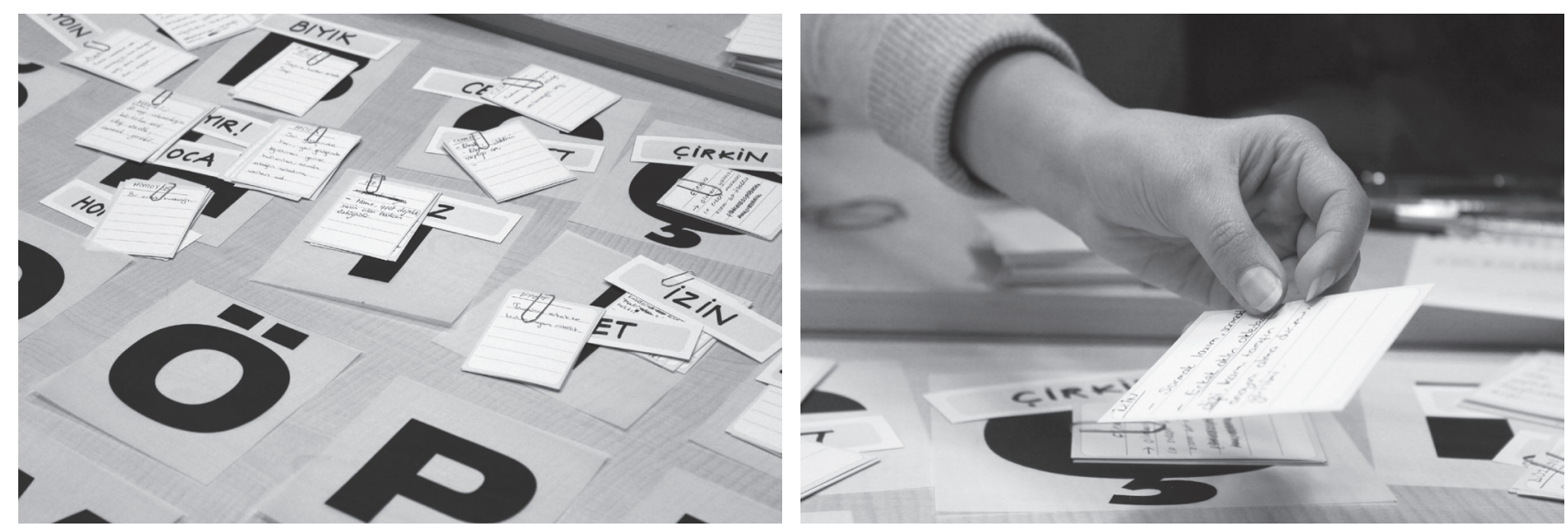

Figure 2. A snapshot from the workshop. Letters, words and definitions attached are aligned on the table.

Figure 3. One of the participants places her definition under the relevant letter.

Figure 4. A page from the dictionary. Redefinition of the word "slut".
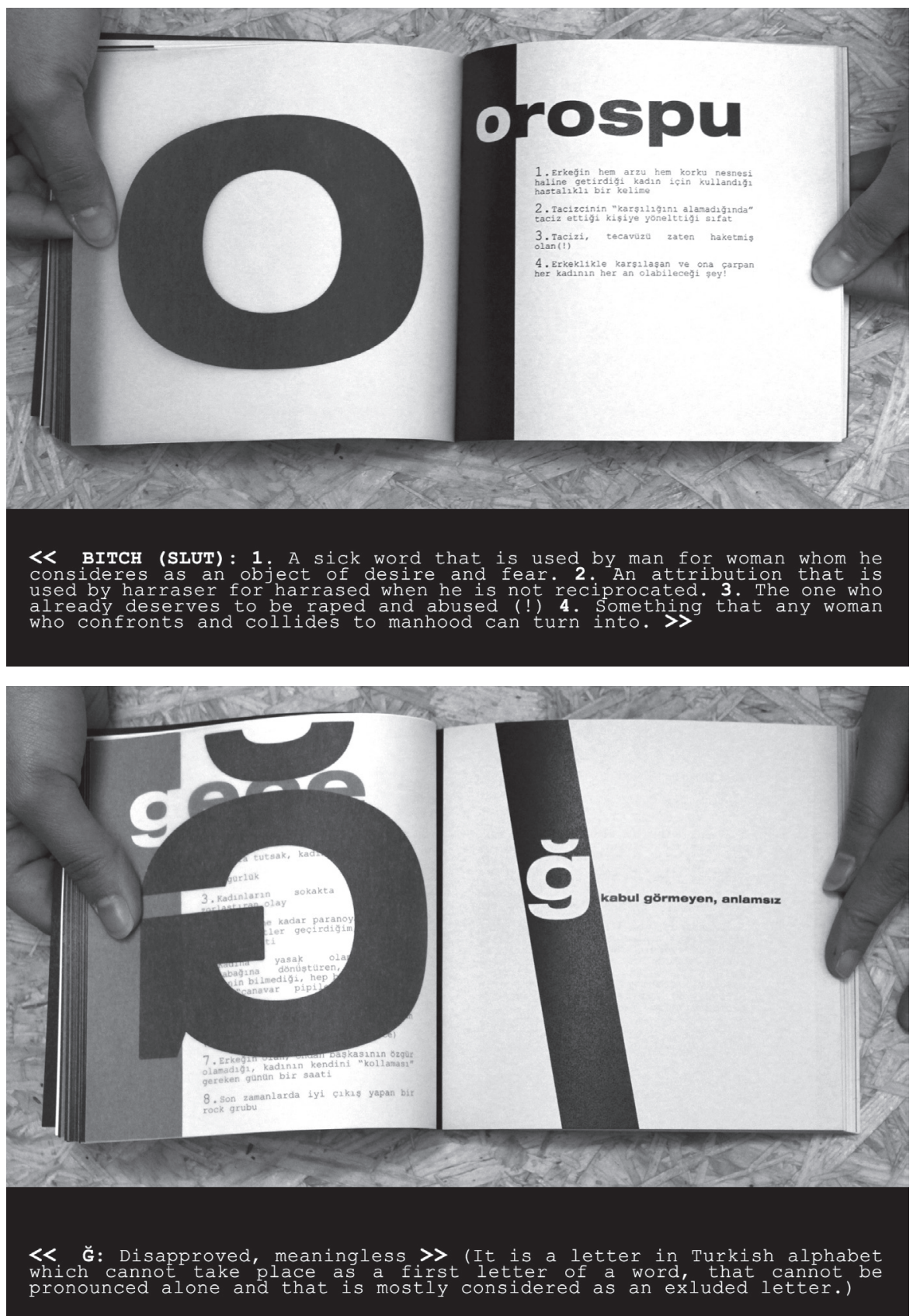
Figure 6. A page from the dictionary. A real-life story about a male gynaecologist, recounted by one of the participants.
Figure 7. Some examples of the hate speech directed at women and taken place in the media.
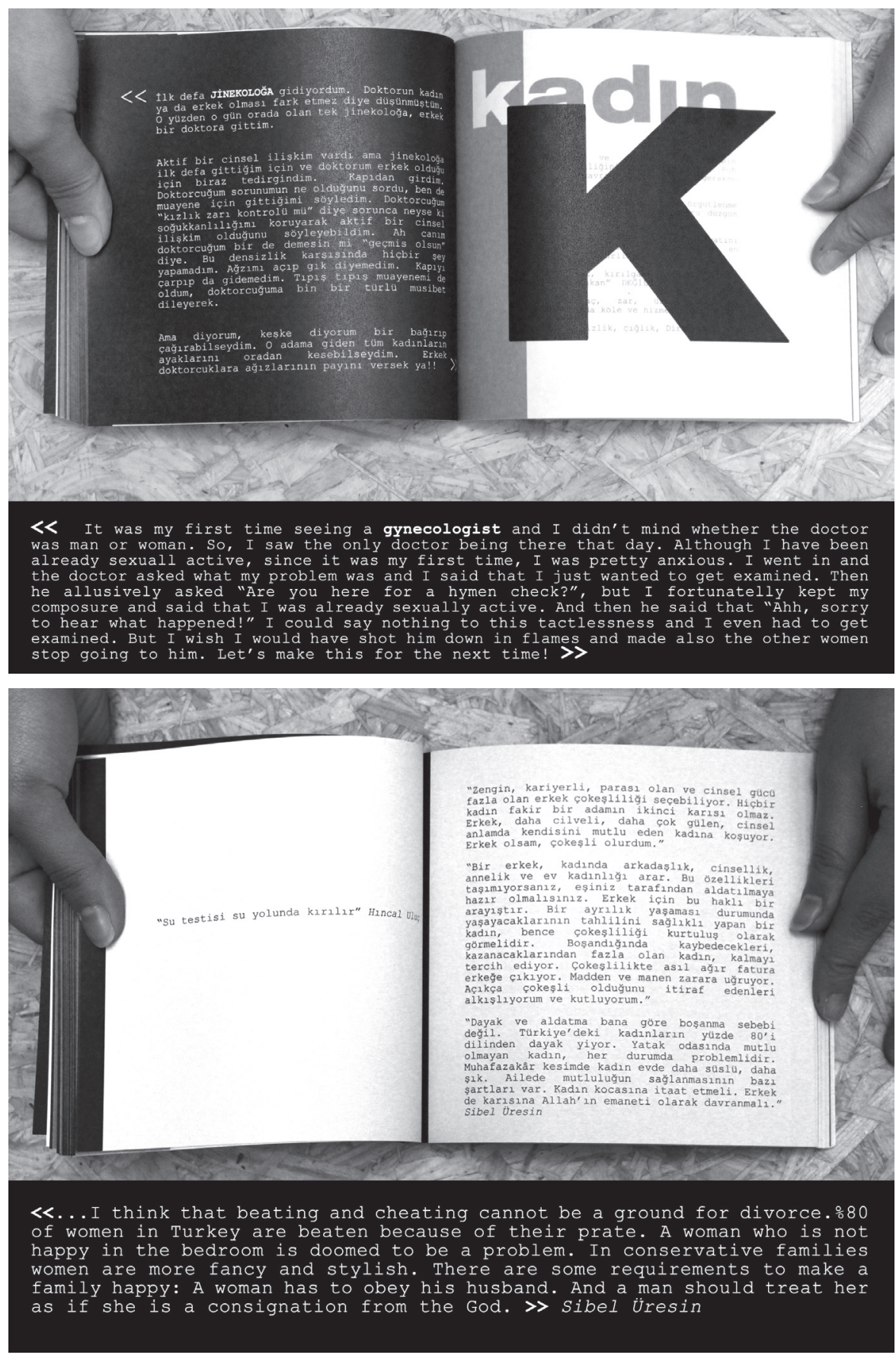

potential encyclopaedia (Field notes, 2012). Some of the participants stated that it was their first time to openly speak about their personal experiences, and they felt empowered by the other people's narratives. One of them expressed that after the 4-hour work of sharing intimate and vulnerable experiences and creating the content intensively, when she saw the dictionary, she had the happy feeling of the outcome being "ours", despite its anonymity (Field notes, 2012). Such feedback about the process and the outcome from the participants demonstrated the empowering potential of design within the group before it went out to encounter the reality outside. 
Figure 8. Photos taken by the participants that depict a tambourine used during the street manifestation against sexual harassment (left) and the windows of the school where an individual experience of sexual harassment took place (right)

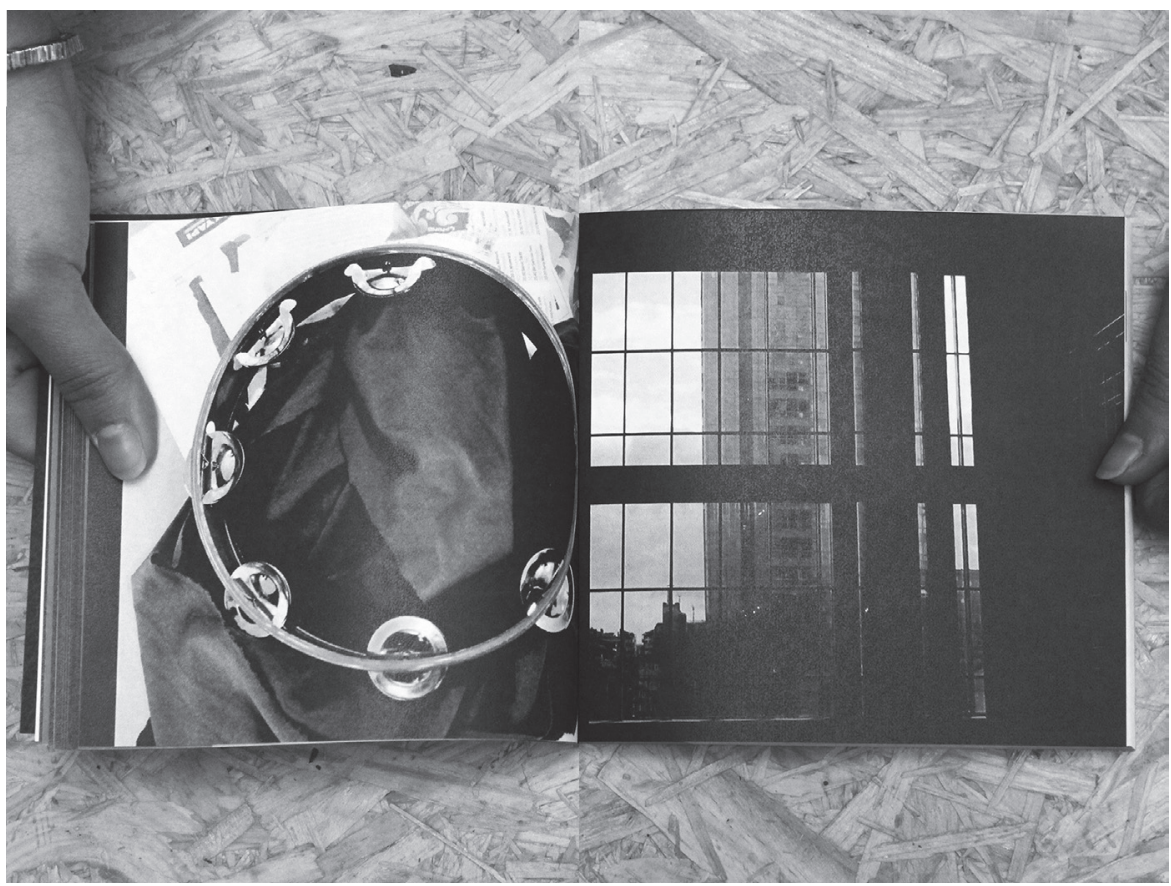

With respect to this intention of direct encounter with people in universities where patriarchy, sexism and machismo beget harassment, we initiated a public intervention with the dictionary as an alternative to unexecuted legislations and a way of making our voices inaudible. As one of the participant expressed,

"This dictionary we made was derived from our trouble, problem and suffer; was not to create a dictionary for its sake [...] This book is a way of saying to the man-dominated world 'Look, this is how we-not you-define and call harassment, this is our experiences."' (Field notes, 2012)

Therefore, we distributed the anonymous dictionary into the library, cafeterias and common areas of the University as the host site for our workshops so that users of these spaces would find themselves confronted with the rewritten definitions, stories and evidence of violence towards women through a black book as an interruptive form of speaking out. Since I was not a regular visitor of the university after this research, other participants had more opportunity and time to observe the moments of interruption. I was later informed by them in the form of informal reports and anecdotes telling that people were curious about the dictionary. The following reactions, especially by college boys, varied from appreciation of the smartness of the dictionary's content to defence. One of the participants recounted how the book paved the way for a relatively long discussion about the topics in the dictionary with one of her male friends when he was compelled to reconsider his own thoughts on the topic from an unexpected perspective.

My first affirmation about the stimulating and challenging power of the dictionary against the man-made world occurred at the very beginning of the process of distribution, in the copy centre. During the protracted process of printing the dictionary, the discomfort of the two technicians in charge became inevitably explicit due to their mimics, whispers and increasing interest in reading the content. It finally led us to have a discussion lasted more than one hour at the end of which they expressed 
their thankfulness of seeing this dictionary and that even if they thought that some concepts would never change in people's mind, it was an important step (Field notes, 2012).

\section{FURTHER REFLECTIONS}

Apart from the feedback from participants and reactions from outsiders, the critical reflections written in my field notes were important, because self-reflexivity plays a crucial role in feminist research especially when the researcher is in "multiple subject positions", as to judge her very own research (Bain and Nash, 2006, 100). Likewise, it helped me to analyse and evaluate the practice and its coherence with the theoretical framework, some of which are articulated below.

First of all, aforementioned context-specific methods adopted for this project were significant, especially in the way participation was handled. The shifted role of activist-designer and that I had already been involved in the group enabled both participants and me to build a convenient environment in which neither design was despised in resistance nor design(er) functioned as expertise. The presence of storytelling and narration built a trustworthy, intimate and friendly environment that helped to empower participants when they heard similarities in each other's stories. The issue of empowerment was also revealed both in selfrepresentation that made women/participants see their words shaped into a circulated artefact and in the collective process of its making. One of the participants expressed that she would have liked to state in the introduction of the dictionary that it was a process of "labour" (Field notes, 2012).

Concerning the content and manner, there were neither didactic nor informative instructions given to the participants, but instead, the process was self-reflexive, spontaneous, satiric and adamant at the same time. Moreover, the dictionary as designed outcome aimed to create a direct expression by women, without prevarication. Apart from that, anonymity was of utmost importance, not only for the participants' security, but also for the project that aimed to demonstrate how personal experiences belong to everyone. For instance, when we were discussing the possible form of the dictionary, I raised the question whether or not our handwriting ought to appear in the book. Two of the participants immediately, if not satirically, uttered that there should not be any recognisable personal sign, but only our collective voice (Field notes, 2012). The question of anonymity was also a critical stance against the exaggerated importance of authorship in today's disciplines, especially in creativity-oriented fields such as design.

In parallel, feedback and reactions to the dictionary demonstrated how a designed artefact, detached from its economic and industrial context and attached to socio-political issues, can raise questions, initiate confrontations and stimulate deliberations as a buttress for women's resistance. It was a remarkable experience to witness the value given by the participants to the dictionary and to the entire process of creating in solidarity. Not only resistance against power and oppression was embodied in a design object as confrontation, but also design was instrumentalised to unravel the predicaments of the human condition and to trigger counteractions in a particular case study.

Surely, to create counter pressure against the oppressive instruments of power that agonise the disenfranchised groups of society including women, 
being an activist is not enough, but new strategies must be developed. Feminist design does not only entail engendering designed artefacts or increasing the number of women working in a male-oriented profession, it also means exercising politics in daily life by utilising design for gender emancipation. Gender activism in design cannot function effectively unless crossing the boundaries of the design discipline as Buckley (1989) stressed long ago, so we should first understand the issue of oppression towards women, not only in the discipline but also in everyday life. Then one can act upon the problem using design tools as the medium, not as a dominator but a catalyst; not by exploiting and representing others, but by contributing to their action and intervening from within a shared realm.

To arrive at that point, in this paper, I suggested that design methodology should be structured as content-specific, because each situation related to human condition and power relations is highly dependent on sociopolitical context and temporal-spatial dynamics. Thus, methods that were proposed in this paper for combating sexual harassment in universities and even the fundamental questions, concerns and analyses that frame such methodologies are open and flexible, for both this issue and other similar ones yet to be de/re-constructed by future practitioners. To conclude, by carving out space for dialogue within design discourse and by exchanging experience within activist groups, it is possible to empower women in resistance with design activity by helping them to reclaim their agency and to represent themselves with their own tools.

\section{ACKNOWLEDGEMENTS}

I would like to thank the women of MSGSU Women's Association, Dikkat Taciz Var! and all the participants as the main actors and shapers of this research. I also express my gratitude to the anonymous reviewers of this article whose contributions to the final text are invaluable.

\section{REFERENCES}

ARENDT, H. (1944) The Jew as Pariah: A Hidden Tradition, Jewish Social Studies 6(2) 99-122.

ATTFIELD, J. (2009)[1989] FORM/female FOLLOWS FUNCTION/male: Feminist Critiques of Design, Design Studies: A Reader, eds. H. Clark and D. Brody, Oxford: Berg Publishers; 49 -53.

BAIN, A. L., NASH, C.J., (2006) Undressing the Researcher: Feminism, Embodiment and Sexuality at a Queer Bathhouse Event, Area 38(1) 99-106.

BINGHAM, S.G., (1994) Introduction: Framing Sexual HarassmentDefining a Discursive Focus of Study, Conceptualising Sexual Harassment as Discursive Practice, ed. S.G. Bingham. Westport, CT: Praeger; 1-4.

BONSIEPE, G. (2006) Design and Democracy, Design Issues 22(2) 27-34.

BOURDIEU, P. (1999) The Space of Points of View, The Weight of the World: Social Suffering in Contemporary Society, eds. P. Bourdieu, trans. P. P. Ferguson. Great Britain: Polity Press in association with Blackwell Publishers Ltd; 3-5.

BUCKLEY, C. (1989) Made in Patriarchy: Toward a Feminist Critique of Design, Design Discourse: History, Theory, Criticism, ed. V. Margolin, Chicago: University of Chicago Press; 251-262. 
BUTLER, J. (1990) Gender Trouble: Feminism and the Subversion of Identity, New York: Routledge.

CANLI, E. (2012) Academy of Silence/Silence of Academy: Design as a Medium, Design as a Political Practice, unpublished MFA Dissertation, Konstfack University, College of Arts, Crafts and Design, Stockholm.

CANLI, E. (2014) [Non]Gendered Desires: Queer Possibilities in Design, DESIGNA2014 Conference Proceedings. Universidade da Beira Interior, Covilhã, Portugal, 20-21 November, 277-87.

CLARK, H. (2009) The Difference of Female Design, Design Studies: A Reader, eds. H. Clark and D. Brody, Oxford: Berg Publishers; 293-7.

CONNELL, R. (1987) Gender and Power: Society, the Person and Sexual Politics, California: Stanford University Press.

DICKER, R.C., PIEPMEIER, A. (2003) Introduction. Catching a Wave: Reclaiming Feminism for the 21st Century, eds. R. Dicker and A. Piepmeier, Boston: Northeastern University Press; 3-28.

EHRNBERGER, K., RÄSÄNEN, M., ILSTEDT, S. (2012) Visualising Gender Norms in Design: Meet Mega Hurricane Mixer and the Drill Dolphia, International Journal of Design [Online] 6(3) [http://www.ijdesign. org/ojs/index.php/IJDesign/article/view/1070/531] Access Date (20.05.2014).

FALS BORDA, O., RAHMAN, M.A., (1991) Action and Knowledge: Breaking the Monopoly with Participatory Action Research, New York: Apex Press.

FERRARA, M., (2012) Design and Gender Studies, Pad Journal 8 [ http:// www.padjournal.net/design-and-gender-studies/\#note-1] Access Date (27. 04. 2014).

FUAD-LUKE, A., (2009) Design Activism: Beautiful Strangeness for a Sustainable World, London: Earthscan.

GAVENTA, J. (1988) Participatory Research in North America, Convergence 24(2-3) 19-28.

GORMAN, C., (2001) Reshaping and Rethinking: Recent Feminist Scholarship on Design and Designers, Design Issues 17(4) 72-88.

HAYES, E., (2007) The Waves of Feminism: Explorations in Open Space and Dissent in the Second Wave Feminist Movement and Its Contributions to the Emergence of Third Wave Feminism, Revisiting Critical Courses [ http://critical-courses.cacim.net/twiki/tiki-index.php] Access Date (27. 04. 2014).

JACKSON, M., (2002) Politics of Storytelling: Violence, Transgression and Intersubjectivity, Copenhagen: Museum Tusculanum Press.

JORGENSEN, D. L., (1989) Participant Observation: A Methodology of Human Studies, California: SAGE Publications.

KAYA, C., (2010) Designer as Enabler: Learning Relationship between a Design and a Non-Designer Maker, LeNS Conference Sustainability in Design NOW: Challenges and Opportunities for Design Research, Education and Practice in the XXI Century, Bangalore, India, 29 September-1st October. 
KAYGAN, P., (2009) Boys Design Cars and Girls Design Dolls? A Case Study on Occupational Segregation in Industrial Design, Design Principles and Practices: An International Journal 3(3) 153-64.

MACKINNON, C.A., (1979) Sexual Harassment of Working Women. New Haven and London: Yale University Press.

MARSHALL, C., ROSSMAN, G., (2006) Data Collection Methods, Designing Qualitative Research, California: SAGE Publications.

MCLAUGHLIN, H., UGGEN, C., BLACKSTONE, A., (2012) Sexual Harassment, Workplace Authority and the Paradox of Power, American Sociological Review XX(X) 1-23.

MORALIOĞLU, A., (2012) Women's Movement in the 80's and Campaigns, Türkiye Barolar Birliği Dergisi 99(2) 291-6.

PAIN, R., WHITMAN, G., MILLEDGE, D. (2012) Participatory Action Research Toolkit, Durham University/RELU/Lune Rivers Trust [https:// www.dur.ac.uk/resources/beacon/PARtoolkit.pdf] Access Date (23.01.2015).

PALUDI, M. (2011) Foreword, Sexual Harassment and Higher Education: Reflections and New Perspectives, eds. B.W. Dziech and M.W. Hawkins, New York: Routledge; ix-xi.

POLKINGHORNE, D.E., (1998) Narrative Knowing and the Human Sciences, New York: State of New York University Press.

POLLETTA, F., (2006) It was Like a Fever: Storytelling in Protest and Politics, London: University of Chicago Press Ltd.

QUINN, B.A., (2002) Sexual Harassment and Masculinity: The Power and Meaning of "Girl Watching", Gender and Society 16(3) 386-402.

RANCIÈRE, J. (2007) The Future of the Image. London: Verso.

RANCIÈRE, J., PANAGIA, D., BOWLBY, R., (2001) Ten Theses on Politics, Theory \& Event 5(3) [http://muse.jhu.edu/] Access Date (12.05.2014).

ROBINETT, J., (2007) The Narrative Shape of Traumatic Experience, Literature and Medicine 26(2) 290-311.

ROBINSON, K. (2012) Sexual Harassment in Schools: Issues of Identity and Power-Negotiating the Complexities, Contexts and Contradictions of This Everyday Practice, Rethinking School Violence: Theory, Gender, Context, eds. K. H. Robinson, S. Saltmarsh and C. Davies. London: Palgrave Macmillan; 71-93.

SANDERS, L., (1997) Against Deliberation, Political Theory 25(3) 347-76.

SPRADLEY, J. P., (1980) Participant Observation, New York: Holt, Rinehart and Winston.

UGGEN, C., BLACKSTONE, A., (2004) Sexual Harassment as a Gendered Expression of Power, American Sociological Review 69 64-92.

YOUDELL, D. (2007) Post Structural Feminist and Queer Action Research, [http://www.tlrp.org/capacity/rm/wt/youdell/\#howto] Access Date (23.01.2015).

YOUNG, I. M., (2000), Inclusion and Democracy, New York: Oxford University Press. 


\section{APPENDIX}

List of the words in the dictionary is below in alphabetical order:

Ahlak (Morals)-Akademi (Academy)-Aydin (Intelligentsia)-Bayan

(Mrs.)-Bekaret (Virginity)-Biyık (Moustache)-Cehalet (Ignorance)-Ceza

(Punishment)-Çirkin (Ugly)-Delikanlı (Lad)-Devlet (State)-

Düzen (The Order of Things)-Ereksiyon (Erection)-Erkek (Man)-Faşizm

(Fascism)-Feminizm (Feminism)-Gece (Night)-Hayır! (No!)-Hoca

(Preceptor)-Homofobi (Homophobia)-Irz (Honour)-İffet (Chastity)-İktidar

(Power)-İzin (Permission)-Jartiyer (Garter)-Jinekoloji (Gynaecology)-

Kadın (Woman)-LGBTT (Lesbian, Gay, Bisexual, Transsexual, Travestite)-

Mastürbasyon (Masturbation)-

Meme (Boob)-Mini Etek (Miniskirt)-Namus (Purity)-Nikah (Wedlock)Orgazm (Orgasm)-Orospu (Slut)-

Örgüt (Mobilisation)-Pipi (Dick)-Polis (Police)-Rıza (Consent)-Seks (Sex)-Sessizlik (Silence)-Sınır (Boundary)-Şiddet (Violence)-Şikayet (Complaint)-Taciz (Harassment)-Tarih (History)-Tecavüz (Rape)Uzlaşmak (Compromise)-Uzman (Expert)-Üniversite (University)-Üzmez (A surname of a public perpetrator)-Vesika (Credential)-Yırtmaç (Slit)YÖK (Institution of Higher Education)-Yönerge (Directives)-Zaman (Time)-Zina (Adultery)

For the digital version of the book in Turkish:

http://issuu.com/cinece/docs/akademide_cinsel_taciz_s_ zl_g_/9?e=2700118/12798124

\section{"SILENCE OF ACADEMY": EXPRESSING HARASSMENT THROUGH COLLECTIVE DESIGN PROCESS}

The aim of this research is to investigate how design can be practised to facilitate self-expression of women, suffering from sexual harassment in universities. The underlying statement, of using design to counteract harassment, is to indicate that design activity can be utilised not only for industrial interests, but also in the realm of socio-political issues such as gender activism and women's struggles. With this aim, in a two-year practice-based design research entitled Silence of Academy, a series of workshops was initiated and facilitated by the design researcher-as the first author of this article-in collaboration with an undergraduate women's association. During the workshops, the undergraduate woman participants, who were directly or indirectly exposed to sexual harassment in universities, sought for an alternative medium to tackle, divulge and speak out the silenced experiences of sexual harassment. By doing so, participants explored the possible ways to create space for their self-representations, not as subordinated or surrendered subjects, but as active agents. They created collective narratives based on their own shared experiences, later captured and amplified by the researcher's design interventions for further actions. At the end of the process, the articulation of harassment was presented as a physical artefact, in the form of a dictionary, also used as a public intervention to encounter the academic milieu beyond the women's circle. 
Alındı: 06.11.2014; Son Metin: 05.01.2016

Anahtar Sözcükler: Cinsel taciz; katılımcı eylem araştırması; sosyal ve politik tasarım; tasarım ve toplumsal cinsiyet; uygulama odaklı tasarım.
In this article, after the issue of sexual harassment and the engagement of women's voices in design is contextualised, the process of design research will be explained through the methodology which is based on participation, storytelling and self-documentation. Moreover, the analysis will focus on how socially-politically engaged design activity can be used to enhance the medium for women's dialogues, and to empower women in resistance by facilitating their self-representations.

\section{AKADEMININ SESSIZLİĞİ: TACİZIN KOLEKTİF TASARIM SÜRECİ YOLUYLA DIŞAVURUMU}

Bu çalışmanın amacı, üniversite sınırları içerisinde cinsel tacize maruz kalmış kadınların kendilerini ifade edebilmelerini kolaylaştırabilmede tasarımın bir araç olarak nasıl kullanılabileceğini araştırmaktır. Böylece, tasarımdan yalnızca endüstriyel değil, toplumsal ve siyasal alanlarda da yararlanılabileceği fikri pekiştirilmek istenmektedir. Bu amaç doğrultusunda ve Akademinin Sessizliği adlı uygulamaya dayalı tasarım araştırması kapsamında, tasarım araştırmacısı-makalenin birinci yazarı-kadınlardan oluşan bir öğrenci topluluğu ile işbirliği içerisinde, bir atölyeler serisi düzenlenmesine ön ayak olmuştur. Gerçekleştirilen atölyelerde, cinsel tacize doğrudan veya dolaylı olarak maruz kalmış üniversiteli kadın katılımcılar tacizle baş edebilmenin, tacizi ifşa edebilmenin ve susturulmuş taciz deneyimlerini yüksek sesle dile getirmenin alternatif yollarını aramışlardır. Bu süreçte katılımcılar, tabi kılınmış ya da teslim alınmış değil, aktif söz söyleyen özneler olarak kendi ifade ve temsil alanlarını yaratmanın imkanlarını araştırmışlardır. Katılımcıların kendi deneyimlerini paylaşarak inşa ettikleri kolektif anlatılar tasarım araştırmacısının müdahalesi ile biçimlendirilmiş ve zenginleştirilmiştir. Sürecin sonunda, tacizin dışavurumu fiziksel bir nesne ile, ortaklaşa tasarlanmış bir sözlük ile somutlaştırılmış; bu sözlük, taciz tartışmasını kadın topluluğunun sınırlarından çıkararak üniversite ortamına yaymak amacıyla kamusal bir müdahale aracı olarak kullanılmıştır. Bu makalede, öncelikle cinsel taciz meselesi ve kadın hakları mücadelesinin tasarımdaki yeri ele alınacak; hemen ardından araştırma süreci, kullanılan yöntembilim ve bu yöntembilimin içinde yer alan katılımcı eylem araştırması, hikaye anlatımı ve öz-belgeleme gibi metotlar eşliğinde açılanacaktır. Bunun yanı sıra, tasarım eyleminin toplumsal ve politik bir müdahale olarak kadın hakları mücadelesinde nasıl bir yeri olduğu, kadınların tacizle ilgili diyaloglarını geliştirmeye nasıl zemin hazırlayabileceği ve kadınların kendi temsillerini yaratabilmede nasıl kolaylaştırıcı olarak kullanılabileceği tartışılacaktır.

ECE CANLI; B.ID., MFA.

Received her MFA in experience design from Konstfack University College of Arts, Crafts and Design and B.Sc. in industrial design from Istanbul Technical University. Her research centres on gendered design, performativity and art \& design as a political practice. Currently continues her research in PhD in Design Program at University of Porto. ece.canli@gmail.com

CIGDEM KAYA; B.I.D., MFA, PhD.

Received her PhD and B.Sc. in industrial product design from Istanbul Technical University (ITU) and MFA in New Genres from San Francisco Art Institute as a Fulbright alumna. Her research interests include tacit knowledge, research through design, the interaction of art and design, and design for NGOs. kayac@itu.edu.tr 